\title{
PENGARUH MODEL PEMBELAJARAN SENTRA PERAN \\ TERHADAP KEMAMPUAN BERBICARA ANAK USIA 5-6 \\ TAHUN DI TK ISLAM AL-KHALIFA SOLEREJO \\ MOJOWARNO JOMBANG
}

\author{
Lailina Farikha \\ Muhammad Busyro Karim \\ Yulias Wulani Fajar \\ Program Studi Pendidikan Guru Pendidikan Anak Usia Dini \\ Fakultas Ilmu Pendidikan Universitas Trunojoyo Madura \\ email: fla.rikha17@gmail.com
}

Received January 2018, Accepted March 2018, Published April 2018

\begin{abstract}
The Influence of Learning Models of Role Centers on Speech Capability of 5-6 Year Old Child in Islamic Kindergarten Al-Khalifa Solerejo Mojowarno Jombang. The purpose of this study was to determine the effect of learning models of role Centers on speech capabilities of child aged 5-6 years old at Al-Khalifa Islamic Kindergarten Ngepung backwoods, Solorejo Village, District Mojowarno, Jombang Regency. This research uses quantitative approach by using Experimental method with design pre-experimental research design(nondesigns) Type of one-grouppre-testposttest.The subject of this study is a child aged 5-6 years old in Islamic Kindergarten AlKhalifa Jombang as many as 17 children's which is representative from the whole number of research. Data collecting technique through the observation and documentation. By using $t$ data experiment analysis (T-Test). The result of data analysis is obtained $r=0,55$ and t-test obtained grade t-count Amount $-0,88$ and t-table 2,178. Then t-table is bigger than $\mathrm{t}$-count $(-2,178>-0,88)$, if $\mathrm{t}$-table $>\mathrm{t}$-count $\mathrm{H} a$ is accepted on standard of significanse $5 \%$ which means there is significant influence between learning model of role center to child's speaking ability.
\end{abstract}

Keywords: Role Centers, Speaking Ability, Early Childhood Education.

\begin{abstract}
Abstrak: Pengaruh Model Pembelajaran Sentra Peran Terhadap Kemampuan Berbicara Anak Usia 5-6 Tahun di TK Islam Al-Khalifa Solerejo Mojowarno Jombang. Tujuan penelitian ini yaitu untuk mengetahui pengaruh model pembelajaran sentra peran terhadap kemampuan berbicara anak usia 5-6 tahun di TK Islam Al-Khalifa Dsn. Ngepung, Desa Solorejo, Kecamatan Mojowarno, Kabupaten Jombang. Penelitian ini menggunakan pendekatan kuantitatif dengan menggunakan metode eksperimen dengan desain penelitian preeksperimental desain (nondesigns) jenis one-group pre-test post-test. Subjek penelitian ini merupakan anak usia 5-6 tahun di TK Islam Al-Khalifa Jombang sebanyak 17 anak yang mewakili dari keseluruhan jumlah penelitian. Teknik pengumpulan data melalui observasi dan dokumentasi. Dengan menggunakan analisis uji t (T-Test). Hasil analisis data yang diperoleh nilai $r=0,55$ dan uji-t yang diperoleh nilai $t_{\text {hitung sebesar -0,88 dan }} t_{\text {tabel }} 2,178$. Maka $t_{\text {tabel }}$ lebih besar dibandingkan dengan $t_{\text {hitung }}$ $(-2,178>-0,88)$, jika $-t_{\text {tabel }}>t_{\text {hitung }} \mathrm{Ha}$ diterima pada taraf signifikasi $5 \%$ yang artinya ada pengaruh signifikan antara model pembelajaran sentra peran terhadap kemampuan berbicara anak.
\end{abstract}

Kata Kunci : Sentra Peran, Kemampuan Berbicara, Pendidikan Anak Usia Dini.

Pendidikan merupakan hal yang sangat penting dan tidak bisa lepas dari kehidupan manusia, sehingga pendidikan sangat penting bagi kelangsungan kehidupan. Seperti yang tercantum pada Undang-Undang Republik Indonesia Nomor 20 Tahun 
46 Jurnal PG-PAUD Trunojoyo : Jurnal Pendidikan dan Pembelajaran Anak Usia Dini, Volume 5, Nomor 1, April 2018, hal 45 - 55

2003 Pasal 1 Tentang Sistem Pendidikan Nasional dinyatakan bahwa:

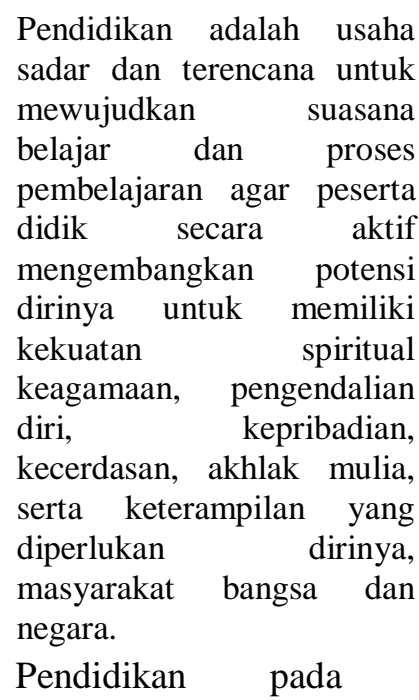

dasarnya merupakan usaha kebudayaan dengan maksud memperluas kualitas hidup dan kehidupan manusia baik secara individual, kelompok masyarakat maupun sebagai suatu bangsa. Oleh karena itu, manusia memiliki aspek kehidupan keberagaman dan kebudayaan, maka pendidikan harus dikembangkan dengan berakar pada nilainilai agama dan kebudayaan masyarakat atau bangsa yang bersangkutan. Seperti Tujuan Pendidikan Nasional pada UndangUndang Republik Indonesia Nomor 20 Tahun 2003 Pasal 3 Tentang Sistem Pendidikan Nasional dinyatakan bahwa:

Tujuan Pendidikan Nasional
adalah untuk
berkembangnya potensi
peseta didik agar menjadi
manusia yang beriman dan
bertaqwa kepada Tuhan
Yang Masa Esa, berakhlak
mulia, sehat, berilmu, cakap,
kreatif, mandiri, dan
menjadi warga negara yang
demokratis
bertanggung jawab.

Pendidikan sangat berarti bagi kehidupan manusia. Untuk kemajuan individual maupun secara kelompok, masyarakat dan bangsa. Pendidikan di indonesia memiliki tiga jalur pendidikan yaitu pendidikan formal, pendidikan nonformal dan pendidikan informal. Dari ketiga jalur pendidikan yang sering dijumpai dan wajib dilakukan adalah jalur pendidikan formal.

Pendidikan formal adalah kegiatan sistematis, berstruktur, bertingkat, berjenjang, dimulai dari sekolah dasar sampai dengan perguruan tinggi dan yang setaraf dengannya, termasuk kedalamnya ialah kegiatan studi yang berorientasi akademik dan umum, program spesialisasi, dan latihan profesional, yang dilaksanakan dalam waktu yang terus menerus. (Coombs dalam Al Rasyid dan Mujtahidin 2013:103). Berdasarkan pengertian tersebut dapat disintesiskan bahwa pendidikan formal yaitu pendidikan yang diselenggarakan di sekolah pada umumnya dan mempunyai jenjang pendidikan yang jelas, mulai dari pendidikan anak usia dini hingga pendidikan perguruan tinggi.

Pendidikan formal di mulai dari pendidikan anak usia dini atau yang sering disebut PAUD. (PAUD) Pendidikan Anak Usia Dini pada hakikatnya adalah pendidikan yang diselenggarakan dengan tujuan untuk memfasilitasi pertumbuhan dan perkembangan anak secara menyeluruh atau menekankan pada pengembangan seluruh aspek kepribadian anak. Oleh karena itu, pendidikan anak usia dini memberi kesempatan bagi anak untuk mengembangkan kepribadian dan potensi secara maksimal (Suyadi,

2014:24). Berdasarkan pengertian tersebut dapat disintesiskan bahwa pendidikan anak usia dini merupakan suatu upaya pembinaan yang dilakukan melalui pemberian rangsangan pendidikan untuk membatu pertumbuhan dan perkembangan anak dalam memasuki pendidikan lebih lanjut.

Secara umum, tujuan Pendidikan Anak Usia Dini adalah memberikan stimulasi atau rangsangan bagi perkembangan potensi anak agar menjadi manusia beriman dan bertakwa kepada Tuhan Yang Maha Esa, berahlak mulia, sehat, berilmu, cakap, kritis, kreatif, inovatif, mandiri, percaya diri, 
dan menjadi warga negara yang demokratis dan tanggung jawab (Suyadi, 2014:24). Berdasarkan Tujuan Pendidikan Anak Usia Dini salah satunya adalah menyediakan berbagai kegiatan yang dapat mengembangkan berbagai aspek pertumbuhan dan perkembangan anak seperti kognitif, agama, bahasa, sosial, emosi, fisik dan motorik. Pada proses pembelajarannya harus disesuaikan dengan keunikan, pertumbuhan dan tahaptahap perkembangan yang dilalui oleh anak usia dini.

$\begin{array}{cccc}\text { Proses pembelajaran pendidikan } \\ \text { anak } & \text { usia dini hendaknya }\end{array}$ diselenggarakan secara menyenangkan, inspiratif, menantang dan memotivasi anak untuk aktif dalam proses belajar, serta memberikan kesempatan anak untuk mandiri dan berkreasi sesuai dengan tahap perkembangan anak. Terdapat beberapa model pembelajaran yang dapat meningkatkan perkembangan anak usia dini diantaranya adalah Model Pembelajaran Berdasarkan Sudut-sudut, Kegiatan Model Pembelajaran Area, Model Pembelajaran Kelompok, dan Model Pembelajaran Berdasarkan Sentra. Model-model pembelajaran tersebut pada umumnya menggunakan langkahlangkah yang relatif sama dalam sehari, yaitu kegiatan awal, kegiatan inti, istirahat/makan, dan kegiatan akhir/penutup (mutiah, 2010:120).

Berdasarkan model pembelajaran pada pendidikan anak usia dini dapat menggunakan berbagai model pembelajaran. Salah satunya yaitu dapat menggunakan model pembelajaran sentra. Model pembelajaran sentra ini sangat bermanfaat untuk diterapkan kepada peserta didik pendidikan anak usia dini, karena sangat bermanfaat untuk mengembangkan potensi yang dimilik oleh setiap individu mengutip Kompasiana.com (http://www.kompasiana.com/agustyai ntan sari/macam-macamkegiatanpembelajaran sentra paud 54f6fa3fa33311170f8b45f2, diakses 27 April 2017). Model pembelajaran sentra merupakan metode pembelajaran yang sangat sesuai dengan tahapan perkembangan anak usia dini. Metode ini dapat mengakomodasi perbedaan individual masing-masing anak (Utin, $d k k, 2009: 2)$.

Sistem sentra merupakan salah satu metode pembelajaran pada program anak usia dini yang berpusat pada anak. Dalam metode ini ruangan ditata sedemikian rupa dalam beberapa sentra. Setiap sentra lebih fokus dalam satu bidang pengembangan, misalnya sentra ibadah, sentra bahan alam, sentra seni dan kreatifitas, sentra persiapan, sentra bermain peran, sentra musik dan olah tubuh, dan sentra balok.

$\begin{aligned} & \text { Setiap sentra } \\ & \text { ditujukanuntuk } \\ & \text { sengembangkan } \\ & \text { seluruhaspek }\end{aligned}$
masing sentra memilikifokus
pengembangan disesuaikan dengan
karakteristik sentranya (Utin, dkk,
2009:2). Dalam model pembelajaran
sentra di rancang sedemikian rupa
untuk memungkinkan anak belajar
dengan pengalaman yang nyata, dan
sesuai dengan tahapan perkembangan
anak.

Setiap sentra memiliki ciri khas tersendiri dalam mengembangkan potensi anak salah satunya yaitu sentra bermain peran dan sering disebut sebagai bermain drama. Bermain peran adalah permainan yang memerankan tokoh-tokoh atau benda sekitar anak sehingga dapat mengembangkan daya khayal (imajinasi) dan penghayatan terhadap bahan kegaitan yang dilaksanakan (Azizah, 2013:23). Bermain peran termasuk salah satu jenis bermain aktif, dimana anak akan bebas melakukan gaya terhadap karakter yang dikagumi atau ditakutinya yang anak temui dalam kehidupan sehari-hari.
Bermain peran memiliki tujuan yaitu untuk melatih anak pada perkembangan bahasa, khususnya melatih anak berbicara dengan lancar dan mampunyai keberanian untuk 
48 Jurnal PG-PAUD Trunojoyo : Jurnal Pendidikan dan Pembelajaran Anak Usia Dini, Volume 5, Nomor 1, April 2018, hal 45 - 55

berbicara di depan kelas. Bermain peran ini melibatkan interaksi sosial dengan manusia lainnya sehingga dapat memperkaya kemampuan berbahasa anak. Sebagaimana menurut Nisa' dan Suryani (2015: 2) bahasa dipelajari oleh anak-anak melalui interaksi sosial dengan orang lain, melalui kesempatan mendengarkan dan menguji coba suara dan kata. Sehingga dengan bermain peran anak akan mampu mengoptimalkan perkembangan bahasanya.

Perkembangan bahasa adalah suatu bentuk komunikasi, baik yang diucapkan, ditulis, atau dengan bahasa isyarat yang didasarkan pada sebuah sistem simbol. Bahasa terdiri dari katakata yang digunakan oleh komunitas serta ketentuan-ketentuan yang diperlukan untuk memvariasikan dan mengombinasikan kata-kata tersebut (Santrock, 2012:187).

Perkembangan bahasa sebagai salah satu kemampuan dasar yang harus dimiliki oleh anak, yang terdiri dari beberapa tahapan sesuai dengan kemampuan dasar dan karakteristik perkembangannya. Berdasarkan standar isi tentang tingkat pencapaian perkembangan anak pada perkembangan bahasa memiliki tiga lingkup perkembangan bahasa yaitu memahami bahasa, mengungkapkan bahasa, dan keaksaraan bahasa. Dari ketiga bahasa ini salah satu kegunaan bahasa yang sering menonjol saat bermain peran yaitu mengungkapkan bahasa, khususnya pada komunikasi secara lisan atau kemampuan berbicara.

\section{Berbicara yaitu}

menyampaikan informasi melalui bunyi bahasa. Berbicara dianggap sebagai kebutuhan pokok bagi masyarakat karena dengan berbicara seseorang dapat menyampaikan dan mengomunikasikan segala isi dan gagasan batin (Madyawati, 2016:90). Pada kemampuan berbicara perlu diperhatikan aspek perkembangan pengucapan, aspek pembentukan kalimat dan aspek isi berbicara, dalam proses belajar sedang berlangsung agar dapat diketahui kemampuan yang dimiliki oleh setiap individu. Kemampuan berbicara dapat dilihat saat anak bermain maupun pada saat belajar melalui anak bermain peran.

Kemampuan berbicara pada
bermain peran merupakan suatu
kosakata yang harus sesuai dengan
tingkat perkembangan bahasa anak
dan berkomunikasi secara lisan.
Berbicara pada anak usia dini
digunakan sebagai model belajar dan
berteman serta melatih kemandirian anak
untuk mengungkapkan ide saat bermain
peran. Pada saat bermain peran anak
akan aktif berbicara baik menggunakan
bahasa indonesia maupun menggunakan
bahasa jawa. Dalam kehiduapan sehari-
hari sering terjadi permasalahan dalam
berbicara, salah satunya seperti
penyampaian kosakata yang kurang
sesuai dengan pola berfikir.

Beberapa

laporan

menyebutkan angka kejadian gangguan bicara dan bahasa berkisar 5-10\% pada anak sekolah. Anak dikatakan mengalami keterlambatan bicara dan harus berkonsultasi dengan ahli, bila sampai usia 12 bulan sama sekali belum mengeluarkan ocehan, sampai usia 18 bulan belum keluar kata pertama yang cukup jelas, padahal sudah dirangsang dengan berbagai cara, terlihat kesulitan mengatakan beberapa kata konsonan, seperti tidak memahami kata-kata yang diucapkan, serta terlihat berusaha sangat keras untuk mengatakan sesuatu, misalnya sampai ngiler atau raut muka berubah Kompasiana.com (http://lifestyle.kompas.c om/read/2009/12/09/13312448/ganggu an.p erkembangan.bahasa.pada.anak, diakses selasa 18 April 2017). Penelitian yang terdahulu menyatakan "laporan penelitian menyebutkan angka kejadian gangguan berbicara dan berbahasa berkisar 5-15\% pada anak sekolah" (Madyawati, 2016:90).

Berdasarkan observasi pertama yang dilaksanakan pada 24 Januari 2017 di kelompok B TK Islam Al-khalifa 


\section{Kecamatan Mojowarno Kabupaten} Jombang. Proses pelaksanaan pembelajaran dimulai anak masuk jam 07.30 bel berbunyi anak baris-berbaris dihalaman sekolah selama 15 menit, untuk membaca ikrar, pancasila, lambang negara dan melakukan motorik kasar diluar kelas. Selanjutnya kegiatan didalam kelas pada sentra peran guru melakukan netralisasi, berdo'a, bernyanyi, dilanjutkan appersepsi dan menjelasan tema dan sub tema. Kegiatan pembelajaran yang pertama guru menjelaskan tempat-tempat rekreasi, tugas-tugasnya dan kegunaannya, selanjutnya guru mengajak peserta didik untuk bermain peran. Saat bermain peran ada anak yang sebagai penjual tiket, pembeli, pemamdu wisata dan ada yang sebagai penjual makan minuman. Setelah anak bermain peran dilanjutkan kegiatan kedua yaitu mewarnai yang sudah disiapkan oleh guru, dan guru mengenalkan ditempat rekreasi ada yang ciptaan allah dan buatan dari manusia.

Proses belajar sedang berlangsung terdapat permasalahan pada perkembangan bahasa anak, khususnya pada kemampuan berbicara. Pada saat berbicara peserta didik TK Islam AlKhalifa sering menggunakan bahasa bercampur-campur, contohnya awalnya anak menggunakan bahasa Indonesia dengan baik dan lancar, saat anak asik berbicara tanpa disadari anak sering terselip bahasa yang berbeda, seperti halnya menggunakan bahasa Jawa yang halus dan terkadang mengucapkan bahasa Jawa yang kasar. Pada permasalah ini sering ditemui pada saat didalam kelas maupun diluar sekolah. Seperti pada penelitian sebelumnya pemasalahan ini terjadi pada peserta didik dikelompok A Tk Al-khalifa

Berdasarkan permasalahan tersebut pada anak dapat diketahui pengucapan anak yang masih kurang tepat dengan indikator perkembangannya, dimana anak terlihat belum mampu mengucapkan suku menjadi kata yang bermakna seperti makan, minum, mandi sakit. Serta terdapat anak belum mampu pada pembentukan kalimat yang sesuai dengan indikatornya, seperti panjang kalimat terdiri 4-5 kata perkalimat dan anak belum mampu menyusun kalimat sederhana dala struktur lengkap SPOK, dan anak masih belum mampu berbicara sesuai sengan topik atau tema pembelajaran.

Hasil pengamatan pada saat proses belajar sedang berlangsung ditemui di kelas TK A yang berjumlah 31 anak. Diantaranya 9 anak yang aktif berbicara namun masih ada bahasa Jawa pada saat berbicara, 9 anak yang cenderung tidak banyak bicara, 8 anak berbicara hanya saat diajak temannya berbicara, dan 5 anak yang tidak masuk sekolah.

Berdasarkan uraian dan permasalahan yang diatas, penulis tertarik untuk meneliti lebih lanjut mengenai kemampuan berbicara anak kelas TK A, dan seiring betambahnya waktu anak beranjak naik kelas TK B atau usia 5-6 tahun.

\section{METODE}

Metode dalam penelitian ini menggunakan kuantitatif yang bersifat eksperimen. Metode eksperimen menurut Sugiyono (2015:72) menyatakan bahwa "Metode penelitian eksperimen dapat diartikan sebagai metode penelitian yang digunakan untuk mencari pengaruh perlakuan tertentu terhadap yang lain dalam kondisi yang terkandalikan". Dalam metode penelitian eksperimen ada perlakuan (treatment), dimana untuk mempengaruhi obyek penelitian dengan anggapan akan terjadi suatu perubahan. Penelitian ini menggunakan design penelitian PreExperimental Design. Sugiyono (2015:74) menyatakan bahwa "Penelitian ini belum merupakan eksperimen sungguh-sungguh, karena masih terdapat variabel luar yang ikut berpengaruh terhadap terbentuknya variabel dependen". Variabel dependen dalam penelitian ini yaitu kemampuan berbicara, sedangkan variabel 
50 Jurnal PG-PAUD Trunojoyo : Jurnal Pendidikan dan Pembelajaran Anak Usia Dini, Volume 5, Nomor 1, April 2018, hal 45 - 55

independennya yaitu, model pembelajaran sentra peran. Penelitian ini menggunakan jenis One-Group PretestPosttest Design yang merupakan bentuk dari Pre-

Experimental Design. Dalam penelitian ini terdapat pretes dan posttest yang dilakukan untuk mengetahui dan membandingkan kemampuan berbicara sebelum dan sesudah diberi perlakuan. Sehingga hasil perlakuan dapat diketahui dengan akurat.

Populasi dalam penelitian ini adalah anak usia 5-6 tahun di TK Islam AlKhalifa Jl.Raya Selorejo, Dsn. Ngepung, Desa Selorejo, Kecamatan Mojowarno, Kabupaten Jombang yang berjumlah 31 anak. Sedangkan sampel pada penelitian ini menggunakan sampel purposive. Menurut Sugiyono (2015:85) sampel purposive adalah teknik penentuan sampel dengan pertimbangan tertentu. Dimana dalam penelitian ini teknik penentuan sampel pada anak yang memiliki permasalahan pada perkembangan bahasa, khususnya pada kemampuan berbicara anak yang berjumlah 17 anak dari keseluruhan jumlah anak usia 5-6 tahun di TK Islam Al-Khalifa.

Teknik pengumpulan data yang digunakan dalam penelitian ini yaitu observasi dan dokumentasi. Penelitian ini menggunakan teknik observasi berupa observasi partisipan. Menurut Sugiyono (2015:154) observasi partisipan atau observasi berperan serta adalah peneliti terlibat dengan kegiatan sehari-hari orang yang sedang diamati atau yang digunakan sebagai sumber data penelitian, dengan observasi partisipan ini, maka data yang diperoleh akan lebih lengkap, tajam, dan sampai mengetahui pada tingkat makna dari setiap perilaku yang nampak.

Sedangkan dokumentasi pada
penelitian ini berupa proses
pembelajaran seperti RPPH (Rencana
pelaksanaan pembelajaran harian) dan
foto-foto kegiatan belajar anak
kelompok B di TK Islam Al-khalifa

selama proses pembelajaran berlangsung mulai dari pretest, treatment, dan posttest.

Perhitungan analisis data dalam penelitian ini menggunakan analisis regresi dengan uji-t (t-test), tujuan uji t adalah untuk mengetahui ada tidaknya pengaruh atau perbedaan nilai rata-rata antara dua kelompok data yang berpasangan. Penggunaan uji-t dua variabel dapat digunakan dengan rumus sebagai berikut:

$$
t=\frac{\bar{x}_{1}-\bar{x}_{2}}{\sqrt{\frac{s_{1}{ }^{2}}{n_{1}}+\frac{s_{2^{2}}}{n_{2}} 2 r\left(\frac{s_{1}}{\sqrt{n_{2}}}\right)\left(\frac{s_{2}}{\sqrt{n_{2}}}\right)}}
$$

Keterangan:

$$
\begin{array}{ll}
\bar{x}_{1} & =\text { Rata-rata pretest } \\
\bar{x}_{2} & =\text { Rata-rata posttest } \\
s_{1} & =\text { Simpangan baku pretest } \\
S_{2} & =\text { Simpangan baku posttest } \\
S_{1}{ }^{2} & =\text { Varians pretest } \\
s_{2^{2}} & =\text { Varians posttest } \\
r & =\text { Korelasi antara } 2 \text { sampel }
\end{array}
$$

Kriteria penilaian,

Jika $-t_{\text {tabel }} \leq t_{\text {hitung }} \leq+t_{\text {tabel }}$, maka $\mathrm{Ha}$ ditolak.

$\mathrm{Jika}-t_{\text {tabel }}>t_{\text {hitung }}>+t_{\text {tabel }}$ maka Ho diterima.

\section{HASIL DAN PEMBAHASAN}

Hasil penelitian dari pengaruh model pembelajaran sentra peran terhadap kemampuan berbicara anak usia 5-6 tahun di TK Islam Al-Khalifa Solerejo Mojowarno Jombang. Menjelaskan secara rinci mengenai pengaruh model pembelajaran sentra peran terhadap kemampuan berbicara anak usia 5-6 tahun di TK Islam AlKhalifa, sebelum adanya perlakuan dan sesudah diberi perlakuan. Adapun hasil 
penelitian ini dapat disajikan dalam tabel 4.1 sebagai berikut:

Tabel 1 Data Selisih (Beda) Nilai

Pretest Dan Postest Kemampuan Berbicara Anak Usia 5-6 Tahun TK Islam Al-Khalifa

\begin{tabular}{|c|c|c|c|c|}
\hline No & Nama & $\begin{array}{l}\text { Rata-rata } \\
\text { Pretest }\end{array}$ & $\begin{array}{c}\text { Rata- } \\
\text { rata } \\
\text { Posttest }\end{array}$ & $\begin{array}{c}\text { Nilai } \\
\text { Beda } \\
\text { antara } \\
\text { Pretest } \\
\text { Posttest }\end{array}$ \\
\hline 1 & ABAR & 1,9 & 3,5 & 1,60 \\
\hline 2 & DRI & 2,1 & 3,5 & 1,40 \\
\hline 3 & EJP & 1,8 & 3,1 & 1,30 \\
\hline 4 & INI & 1,4 & 3,2 & 1,80 \\
\hline 5 & $\mathrm{JNH}$ & 1,7 & 3,3 & 1,60 \\
\hline 6 & JAP & 1,9 & 3,3 & 1,40 \\
\hline 7 & MADA & 1,9 & 3,6 & 1,70 \\
\hline 8 & MFAK & 1,8 & 3,3 & 1,50 \\
\hline 9 & MHLO & 1,5 & 3,4 & 1,90 \\
\hline 10 & MHE & 1,9 & 3,5 & 1,60 \\
\hline 11 & NAF & 2 & 3,4 & 1,40 \\
\hline 12 & ODP & 1,9 & 3,5 & 1,60 \\
\hline 13 & $\mathrm{RS}$ & 1,9 & 3,2 & 1,30 \\
\hline 14 & RNA & 2 & 3,4 & 1,40 \\
\hline 15 & RDA & 2 & 3,4 & 1,40 \\
\hline 16 & TS & 2,1 & 3,8 & 1,70 \\
\hline 17 & ZHPR & 1,7 & 3,2 & 1,50 \\
\hline
\end{tabular}

Tabel 1 diatas merupakan data hasil pengamatan sebelum perlakuan (prettest) dan sesudah perlakuan (posttest) tentang kemampuan berbicara anak usia 56 tahun di TK Islam Al-Khalifa Dsn. Ngepung Desa Solorejo Kecamatan Mojowarno Kabupaten Jombang yang telah ditentukan sebagai sampel yang mewakili dari penelitian ini yaitu 17 anak dari keseluruhan jumlah anak. Data yang terkumpul diatas merupakan nilai dari 6 indikator kemampuan berbicara anak yaitu mengucapkan huruf mati seperti $(\mathrm{z}, \mathrm{w}, \mathrm{d}$, s dan $\mathrm{g})$ dan huruf kombinasi mati (st, sr,dr, dan fl), menyebutkan nama dan jenis kelamin, mengucapkan suku kata, panjang yang terdiri dari 4-6 kata perkalimat, menyusun kalimat sederhana dalam struktur lengkap SPOK (kalimat subjek predikat - objek - keterangan), dan kesesuaian topik atau tema pada berbicara.

Kemampuan berbicara anak sebelum perlakuan (treatment), menggunakan model pembelajaran sentra peran besar (makro) secara kumulatif terdapat 15 anak yang nilainya tergolong mulai berkembang (MB), 2 anak tegolong berkembang sesuai harapan (BSH) dan tidak ada yang tergolong berkembang sangat baik (BSB). Sedangkan kemampuan berbicara anak sesudah diberikan perlakuan (treatment) menggunakan model pembelajaran sentra peran besar (makro) rata-rata anak tergolong berkembang sangat baik (BSB).

Berdasarkan pada tabel 1 diatas dapat dilihat bahwa tiap anak usia 5-6 tahun (kelompok B) TK Islam AlKhalifa mengalami peningkatan nilai kemampuan berbicara setelah peneliti melakukan treatment atau perlakuan dengan menggunakan model pembelajaran sentra peran besar (makro). Selain berdasrkan paparan dan hasil 4.1 dapat juga dibuktikan dari hasil perhitungan yang telah dilakukan peneliti dan dapat diketahui bahwa hipotesis $(\mathrm{Ho})$ ditolak dan hipotesis alternative $(\mathrm{Ha})$ diterima.

Berdasarkan perhitungan hasil uji hipotesis tersebut menggunakan uji-t yang diperoleh nilai $t_{\text {hitung }}$ sebesar $-0,88$ dan $t_{\text {tabel }} 2,178$. Maka $t_{\text {tabel }}$ lebih besar dibandingkan dengan $t_{\text {hitung }}(-2,178>-$ $0,88)$, jika $-t_{\text {tabel }}>t_{\text {hitung }}$, Ha diterima yang artinya da pengaruh yang signifikan pembelajaran sentra peran terhadap kemampuan berbicara anak usia 5-6 tahun di TK Islam Al-Khalifa Dsn. Ngepung, Desa Solorejo,

Kecamatan Mojowarno, Kabupaten Jombang.

Berdasarkan hasil perhitungan yang telah dilakukan dapat diketahui model pembelajaran sentra peran berpengaruh terhadap kemampuan berbicara anak usia 5-6 tahun. Model pembelajran sentra mempunyai banyak macam-macam pembelajaran diantaranya yaitu sentra persiapan, 
52 Jurnal PG-PAUD Trunojoyo : Jurnal Pendidikan dan Pembelajaran Anak Usia Dini, Volume 5, Nomor 1, April 2018, hal 45 - 55

sentra balok, sentra main peran besar, sentra main peran kecil, sentra bahan alam, sentra seni, dan sentra imtaq.

Berdasarkan beberapa macammacam pembelajaran sentra pada anak usia dini memiliki definisi dan tujuan yang berbeda namun masing-masing sentra saling menunjang dan mendukung perkembangan anak. Salah satu bentuk model pembelajaran sentra yang diamati oleh peneliti yaitu sentra peran atau yang sering disebut bermain peran peran (role playing) merupakan turunan dari konsep sosiodrama, yaitu sebuah metode untuk menjelajah isu yang terlibat dalam situasi sosial yang kompleks. Istilah "peran" berhubungan dengan naskah yang menjadi bagain dari perkerjaan aktor dalam memerankan sebuah adegan. Hal ini pertama kali terjadi kurang lebih pada dua ribu tahun yang lalu di Yunani Kuno. Di dalam bermain peran ini terdapat semacam kekuatan yang mampu menghadirkan jenis kegiatan imajinatif yang bisa dilakukan oleh anak-anak dalam bermain pura-pura (Haenilah, 2015:123).

Berdasarkan macam-macam pembelajaran sentra peran terdapat 2 model pembelajaran sentra peran yaitu sentra main peran besar (makro) dan sentra main peran kecil (mikro). Dalam penelitian ini peneliti menggunakan treatmen dengan cara sentra main peran besar (makro), sentra bermain besar disebut juga main simbolik, role play, pura-pura, make belive, fantasi, imajinasi, atau main drama. Sentra main besar adalah sentra yang memberikan kesempatan kepada anak untuk mengembangkan pengertian mereka tentang dunia disekitarnya, kemampuan berbahasa, keterampilan mengambil sudut pandang dan empati melalui main peran yang mengalirkan pengentahuan pada anak. Bertujuan untuk mengembangkan kemampuan interaksi sosial dan berbahasa, dan membangun rasa empati, mengambil sudut pandang spasial afeksi (Latif, 2013:124).

Penggunaan sentra peran besar (makro) pada saat treatmen dilakukan karena alat atau media main peran besar adalah alat dengan ukuran yang sesungguhnya. Artinya, alat tersebut bisa dipakai anak saat bermain. Pelengkapan main peran di sentra mian peran besar dibagi atas: alat dan bahan main kerumah tanggaan, alat dan bahan main keprofesian, alat dan bahan main yang mendukung keaksaraan (Latif, 2013:133). Sehingga kemampuan berbicara anak akan aktif dan bisa diamati untuk mengetahui peningkatan sesudah diberikan treatmen. Berdasarkan penggunaan sentra besar dapat diketahui pada kemampuan akhir sesudah perlakuan (posttest) yang awalnya anak kemampuan berbicara pada pengucapannya belum berkembang (BB) menjadi mulai berkembang (MB), dan awalnya anak mulai berkembang (MB) menjadi berkembang sesuai harapan (BSH).

Model pembelajaran sentra peran pada anak usia dini dapat mengembangkan berbagai aspek perkembangan yang sesuai dengan pertumbuhan yang dimiliki oleh individu anak. Berikut adalah beberapa macammacam perkembangan menurut berbagai pendapat, namun dalam pelaksanaan penelitian ini tidak semua perkembangan tersebut muncul. Salah satunya yaitu perkembangan bahasa.

Perkembangan bahasa menurut beberapa pendapat yaitu, "suatu bentuk penyampaikan pesan terhadap segala sesuatu yang diinginkan. Dengan bahasa, orangtua atau pendidik akan tahu apa yang menjadi keinginan anaknya. Bahasa didenfinisikan sebagi sarana komunikasi dengan orang lain. Dalam pengertian ini, mencakup semua cara untuk berkomunikasi, dimana pikiran dan perasaan dinyatakan dalam bentuk lisan, tulisan, isyarat, atau gerak dengan menggunakan kata-kata, simbol, lambang, gambar atau likisan"(Fadillah, 2012:38). Berdasarkan teori tersebut terbukti dilapangan pada saat treatmen anak mampu berkomunikasi dimana pikiran dan perasaan dinyatakan dalam bentuk lisan seperti; anak bertanya apa yang akan diperajari?, mau dibuat apa 
biji-bijian ini?. Serta anak mampu menyampaikan pesan terhadap segala sesuatu yang diinginkan saat berperan.

Berdasarkan model
pembelajaran sentra peran pada
macam-macam perkembangan anak usia dini yang sering ditemui dilapangan adalah perkembangan bahasa. Hal ini terbukti bahwa model pembelajaran sentra peran dapat meningkatkan perkembangan bahasa khususnya kemampuan berbicara anak usia 5-6 tahun, dan perkembangan tersebut sesuai dengan teori perkembangan bahasa anak. Adapun teori perkembangan bahasa yang dijumpai peneliti saat penelitian yaitu teori nativistik, teori behavioristik, teori kognitif, teori pragmatik, dan teori interaksionis.

Berdasarkan teori perkembangan bahasa khususnya kemampuan berbicara anak yang pertama ditemui peneliti saat pelaksanaan pembelajaran sentra peran yaitu teori nativistik. "Para ahli nativis menjelaskan bahwa kemampuan bahasa dipengaruhi oleh kematangan seiring dengan pertumbuhan anak. Pandangan para ahli nativis yang memisahkan antara belajar bahasa dengan perkembangan kognitif dikritik berkenaan dengan kenyataan bahwa anak belajar bahasa dari lingkungan sekitarnya dan memilki kemampuan untuk mengubah bahasanya jika lingkungannya berubah" (Dhieni, 2013:2.3).

Berdasarkan teori tersebut terbukti dilapangan pada saat treatmen, anak mampu belajar bahasa dari lingkungan sekitarnya dan memilki kemampuan untuk mengubah bahasanya seperti; guru yang mengajarkan berbicara pada anak untuk mengucapkan bahasa Indonesia yang tepat sesuai peran yang dimainkan, hal ini terbukti bahwa lingkungan sekitarnya mampu mengubah bahasa anak yang sebelumnya berbicara bahasa Jawa dan berubah berbicara mengucapkan bahasa Indonesia.
Berdasarkan teori perkembangan bahasa yang kedua ditemui peneliti saat pelaksanaan pembelajaran sentra peran yaitu teori behavioristik. "Para ahli teori behavioristik berpendapat bahwa anak dilahirkan tanpa membawa kemampuan apapun. Dengan demikian anak harus belajar (dalam hal ini belajar berbahasa) melalui pengkondisian dari lingkungan, proses imitasi, dan diberikan reinforcement (penguat)" (Dhieni, 2013:2.9).

Hal ini terbukti seperti pada teori tersebut dimana belajar berbahasa khususnya berbicara melalui pengkondisian dari lingkungan dan proses imitasi, terlihat saat pengambilan dataPara ahli pragmatik berpendapat bahwa anak belajar bahasa dalam rangka sosialisasi dan mengarahkan perilaku orang lain agar sesuai dengan keinginannya. Teori pragmatik berasumsi bahwa anak selain belajar bentuk dan arti bahasa, juga termotivasi oleh fungsi bahasa yang bermanfaat bagi merekaanak mampu belajar berbicara seperti yang sudah dicontohkan oleh guru berbicara sesuai peran yang dimainkan.

Berdasarkan teori perkembangan bahasa yang ketiga ditemui peneliti saat pelaksanaan pembelajaran sentra peran yaitu teori pragmatik. "Para ahli pragmatik berpendapat bahwa anak belajar bahasa dalam rangka sosialisasi dan mengarahkan perilaku orang lain agar sesuai dengan keinginannya. Teori pragmatik berasumsi bahwa anak selain belajar bentuk dan arti bahasa, juga termotivasi oleh fungsi bahasa yang bermanfaat bagi mereka" (Dhieni, 2013:2.21). Hal ini terbukti seperti pada teori tersebut dimana belajar bahasa khususnya pada kemampuan berbicara melalui teori ini yang menyatakan berasumsi bahwa anak selain belajar bentuk dan arti bahasa, terlihat saat pengambilan data posttest anak mampu menyatakan kalau sering minum jus buah badan akan menjadi sehat dan tidak mudah sakit. Hal tersebut diketahui anak dapat membentuk kalimat, serta dapat 
54 Jurnal PG-PAUD Trunojoyo : Jurnal Pendidikan dan Pembelajaran Anak Usia Dini, Volume 5, Nomor 1, April 2018, hal 45 - 55

mengucapkan kata dan suku menjadi kata yang bermakna.

Berdasarkan teori perkembangan bahasa yang keempat ditemui peneliti saat pelaksanaan pembelajaran sentra peran yaitu teori kognitif. Piaget dalam Dhieni mengungkapkan "berpikir sebagai prasyarat berbahasa, terus berkembang sebagai hasil dari pengalaman dan penalaran. Perkembangan bahasa bersifat progresif dan terjadi pada setiap tahap perkembangan. Perkembangan anak secara umum dan perkambangan bahasa awal anak berkaitan erat dengan berbagai kegiatan anak, objek, dan kejadian yang mereka alami dengan menyentuh, mendengar, melihat, merasa, dan membau" (Dhieni, 2013:2.15).

Hal ini terbukti seperti pada teori tersebut dimana belajar kemampuan berbicara melalui teori kognitif yang menyatakan perkembangan bahasa bersifat progresif dan terjadi pada setiap tahap perkembangan. Terlihat saat pengambilan data posttest dimana perkembangan berbicara anak memiliki perubahan berbicara, yang awalnya anak belum berkembang menjadi mulai berkembang, dan yang awal anak berkembang sesuai harapan menjadi berkembang sangat baik.

Berdasarkan teori perkembangan bahasa yang kelima ditemui peneliti saat pelaksanaan pembelajaran sentra peran yaitu teori interaksionis. "Kajian tentang teori interaksionis bertitik tolak dari pandangan bahwa bahasa merupakan perpaduan faktor genetik dan lingkungan. Kemampuan kognitif dan berbahasa diasumsikan terjadi secara bersamaan. Seorang anak dilahirkan dengan kemampuan untuk mempelajari dan mengemukakan bahasa, dan kemampuan berinteraksi dengan lingkungannya yang mencakup imitasi, reinforcement, reward, dan peran sosial" (Dhieni, 2013:2.26).

Hal ini terbukti seperti pada
teori tersebut dimana belajar
kemampuan berbicara melalui teori ini yang menyatakan perpaduan faktor genetik dan lingkungan, terlihat saat pemberian treatment dimana saat guru memberikan stimulus terlihat beberapa anak yang masih dalam mulai berkembang, saat guru mengajarkan anak berbicara mengucapkan bahasa Indonesia terlihat anak yang tetap pada mengucapkan mengggunakan bahasa Jawa, hal ini terbukti pada faktor genetik dan lingkungan dirumah anak.

Berdasarkan hasil penelitian yang dipadukan dengan berbagai uraian teori perkembangan bahasa yang mendukung, perhitungan uji hipotesis menggunkan uji-t mendapatkan hasil yang dapat menjawab rumusan masalah bahwa ada pengaruh model pembelajaran sentra peran terhadap kemampuan berbicara anak usia 5-6 tahun di TK Islam Al-Khalifa Solerejo Mojowarno Jombang.

\section{KESIMPULAN}

Berdasarkan hasil penelitian yang telah dilakukan menunjukkan bahwa anak usia 5-6 tahun yang berjumlah 31, dan subjek penelitian sebanyak 17 anak yang mewakili dari keseluruahan jumlah penelitian. Terdapat perbedaan nilai kemampuan berbicara antara pretest dan posttest. Pada saat pretest terdapat 12 anak yang nilainya tergolong mulai berkembang (MB), 5 anak yang tergolong berkembang sesuai harapan (BSH), dan tidak ada anak yang tergolong berkembang sangat baik (BSB), sedangkan pada saat posttest terdapat nilai rata-rata keseluruhan anak berkembang sangat baik (BSB).

Berdasarkan hasil uji hipotesis tersebut menggunakan uji-t yang diperoleh $t_{\text {hitung }}$ sebesar $-0,88$ dan $t_{\text {tabel }}$ 2,178 . Maka $t_{\text {tabel }}$ lebih besar dibandingkan dengan $t_{\text {hitung }}(-2,178>-$ $0,88)$, jika $-t_{\text {tabel }}>t_{\text {hitung }}$, Ha diterima yang artinya da pengaruh yang signifikan pembelajaran sentra peran terhadap kemampuan berbicara anak usia 5-6 tahun di TK Islam Al-Khalifa 
Jurnal PG-PAUD Trunojoyo : Jurnal Pendidikan dan Pembelajaran Anak Usia Dini, Volume

Dsn. Ngepung, Desa Solorejo,

Kecamatan Mojowarno, Kabupaten Jombang.

\section{DAFTAR PUSTAKA}

Agustyaintansari. (2014). MacamMacam Kegiatan Pembelajaran Sentra PAUD, (online) (http://www.kompasiana.com/ag ustyaintansari/macam-macamkegiatan-pembelajaransentra paud_54f6fa3fa33311170f8b45f 2), Diakses 27 April 2017.

Al Rasyid, H. \& Mujtahidin. (2013). Ilmu Pendidikan, Madura: Utm pers

Dhieni, N. (2013). Metode Pengembangan Bahasa, Tangerang: Universiatas Terbuka Een Y.Haenilah, E. 2015. kurikulum dan pembelajaran PAUD. Yogyakarta; Media Akademi Fadillah, M. 2012. Desain Pembelajaran PAUD. Jogjakarta: Ar-Ruzz Media.

Kompas.com. 2009. Gangguan Perkembangan Bahasa pada Anak, (online), (http://lifestyle.kompas.com/rea d/2009/12/09/13312448/ganggu an.perkembangan.bahasa.pada.a nak), diakses selasa 18 April 2017.

Latif, M, dkk. (2013). Orientasi Baru Pendidikan Anak Usia Dini. Jakarta: PT Fajar Interpratama Madiri.

Madyawati, L. (2016). Strategi Pengembangan Bahasa Pada Anak. Jakarta: Prenada Media Group.

Mutiah, D. (2010). Psikologi Bermain Anak Usia Dini. Jakarta: Prenada Media Group.
Nisa', T. F. dan Suryani, I. W. (2015). Meningkatkan Keaktifan Berbicara dan Kemampuan Matematika Anak Melalui Media Ular Tangga. Jurnal $P G$ PAUD Trunojoyo : Jurnal Pendidikan dan Pembelajaran Anak Usia Dini. (Online). (http://infestasi.trunojoyo.ac.id/p gpaudtrunojoyo/article/view/182 0/1509), diakses 15 September 2017.

Nur, A. (2013). Tingkat Keterampilan Berbicara Ditinjau Dari Metode Bermain Peran Pada Anak Usia 5-6 Tahun. Skripsi (Online). (http://lib.unnes.ac.id/18753/1/1 601409035.pdf), diakses Rabu 19 April 2017.

Santrock, J, W. (2012). Life-Span Development Perkembangan Masa-Hidup. Jakarta: PT Gelora Akasara Pratama.

Sugiyono. (2015). Metode Penelitian Pendidikan Pendekatan

Kuantitatif, Kualitatif, dan $R \& D$. Bandung: Alfabeta.

Suyadi. (2014). Teori Pembelajaran Anak Usia Dini Dalam Kajian Neurosains. Bandung: PT Remaja Rosdarkarya

Undang-Undang Republik Indonesia No. 20 Tahun 2003 Tentang Sistem Pendidikan Nasional. 2008. Jakarta.

Utin, dkk. (2009). Panduan penyelenggara sentra pada kelompok bermian. Surabaya: Depertemen Pendidikan Nasional 